Verboord, M., Kuipers, G., \& Janssen, S. (2015).

Institutional recognition in the transnational literary field, 1955-2005.

Cultural Sociology. Online first April 6, 2015, doi: 10.1177/1749975515576939

http://dx.doi.org/10.1177/1749975515576939

\title{
Institutional recognition in the transnational literary field, 1955-2005
}

\author{
Marc Verboord (Erasmus University Rotterdam) ${ }^{1}$ \\ Giselinde Kuipers (University of Amsterdam) \\ Susanne Janssen (Erasmus University Rotterdam)
}

\begin{abstract}
Contributing to research on social processes of cultural de-hierchization, this article explores how critical recognition in elite newspapers is related to the recognition that authors receive from other agents in the literary field in the past half-century. We distinguish four types of institutional recognition: (a) long-term recognition in literary encyclopedias, (b) short-term recognition through literary awards, (c) recognition through bestseller list success, and (d) recognition through the prestige of publishers. Our study uses a sample of articles from 1955, 1975, 1995 and 2005 in French, German, Dutch and US elite papers $(N=2,419)$, as well as further information on the extent to which fiction book authors discussed in the newspaper sample received the above forms of institutional recognition. We conduct cluster analysis to inductively establish how these forms of recognition are related, and multinomial logistic regression analysis to predict membership of clusters. Throughout the period 1955-2005 we consistently find three author categories: the unrecognized, the contemporary prestigious, and the historical prestigious. Countries differ, however, in the extent to which these categories are represented in newspaper' literary coverage. Our analysis of factors determining membership of these clusters points to the lasting importance of symbolic capital, but also to the transnational nature of institutional recognition as local and international recognition show highly similar patterns.
\end{abstract}

Key words: institutional recognition; cultural legitimation; literature; literary; literary field; arts journalism; transnational; transnational cultural production; newspapers; critics; criticism; cultural hierarchies; de-hierarchization

\footnotetext{
${ }^{1}$ Marc Verboord, Erasmus School of History, Culture and Communication, Dept. of Media and Communication, P.O. Box 1738, 3000 DR Rotterdam, Netherlands. Email: verboord@eshcc.eur.n
} 


\section{Introduction}

Since the mid-twentieth century, the literary fields of Western countries have undergone profound changes. The status of high arts has declined, and hierarchical distinctions within the literary field have eroded (Peterson \& Kern, 1996; Collins, 2010). Moreover, commercial pressures on publishers and authors have increased, new genres have emerged (Sapiro, 2003, 2010; Thompson, 2010; Verboord, 2011; Franssen \& Kuipers, 2013), and the issuing of literary awards has evolved into media spectacles (Street, 2005; English, 2005). Also, one of the traditionally most influential institutions in the production of symbolic value (Van Rees, 1987; Janssen, 1997; Baumann, 2007) - literary criticism in elite newspapers - has seen transitions. Between 1955 and 2005, the newspaper coverage of arts and culture in general, and literary books specifically, has expanded, become more diversified in form, become more international and has shifted its attention from highbrow culture to popular culture (Janssen et al., 2008, 2011; Janssen, 2009; Kristensen, 2010). Yet, how do these developments come together? Are processes and practices of symbolic production changing under influence of commercial pressures? Previous work on the production of symbolic value has emphasized the collective nature of this endeavor (e.g. Van Rees \& Dorleijn, 2001; Baumann, 2007), yet few studies have examined for the literary field how symbolic recognitions of authors by different institutional agents are linked to each other and how these relations evolve over time.

In this paper we analyze how critical recognition in elite newspapers is related to the recognition that authors receive from other agents in the literary field. Critics and editors operating in elite newspapers -- defined as those newspapers that principally target higher educated social classes and whose coverage emphasizes political, economic, and cultural affairs - are influential agents in the symbolic production of culture (Van Rees, 1987; Shrum, 1991; Janssen, 1997; Baumann, 2007). Mediating between semi-autonomous art worlds and 
audiences who rely upon media to inform themselves on the cultural goods on offer, newspaper critics and editors shape public opinions about the importance or "legitimacy" of cultural products (Bourdieu, 1980; Becker, 1982; Van Rees \& Vermunt, 1996). Thus, elite newspapers have an important role in establishing and disseminating what is considered "valuable" culture in society, ultimately affecting school curricula and ideas on cultural capital (Bourdieu, 1984; Van Rees, 1983; DiMaggio, 1991). Previous work has highlighted how critics in elite newspapers function as gatekeepers by making first selections and evaluations from the large cultural supply (e.g. Van Rees, 1987; Shrum, 1991; Janssen, 1997; Curran, 2000). Yet, while it has been argued that critics avoid deviations from the literary norm at a given moment (Van Rees, 1987; Janssen, 1997), empirical research on how critics incorporate information from other institutional sources is still scarce- especially from a longitudinal perspective. Nevertheless, such enterprise would give us more insight in how the production and perception of cultural value have developed against the backdrop of wider societal and cultural changes (see DiMaggio, 1991). For instance, the growth in omnivorous cultural participations has been associated with a decline of cultural authority (e.g. Peterson \& Kern, 1996). Determining the degree to which value attributions of literary critics and editors in elite newspapers overlap with those generated by other agents in the literary field both"legitimate" ones (such as the literary encyclopedia entries written by literary scholars) and less legitimate ones (e.g. bestseller lists published by the book trade) - might thus elucidate whether and how cultural evaluations across relevant institutions diverge or converge over time.

Declining readerships and decreasing cultural authority may have changed the status of newspaper criticism as a legitimizing institution (e.g. Janssen et al., 2011). This study starts from the assumption that symbolic recognition - defined here as the acceptance of widespread consensual beliefs on cultural value - is a collective construction of social reality in 
which institutional agents, e.g. newspaper critics, play a leading role (Johnston et al., 2006). Institutions, then, play a central role in legitimizing processes because they endow cultural products with value. Scholarship on processes of cultural legitimation and evaluation has employed various analytical strategies. Historical-sociological accounts (e.g. DiMaggio 1982; 1992) have highlighted the institutional basis of cultural capital by analyzing the trajectories of cultural institutions. Content analyses of texts produced by critics show how aesthetic and critical discourses shape and legitimate attributions of cultural value (e.g. Baumann, 2007; Kersten \& Bielby, 2012). Others have analyzed to what extent recognition in one institutional context meets with approval in others, thereby expressing consensual beliefs about cultural value (e.g. Allen \& Lincoln, 2004; Verboord \& Van Rees, 2009; Braden, 2009). This article follows the latter strategy.

Concretely, we are interested in the extent to which the evaluations by critics and editors operating in elite newspapers are in agreement with those generated by various other agents in the literary field, and whether this changes over time. For instance, to what extent does the increasing role of bestsellers (Thompson, 2010) manifest itself in the coverage given to different categories of literary authors? Moreover, we are interested in the extent to which authors deemed important in one national field meet with approval in other national contexts.

We employ a cross-national comparative design for several reasons. First, this allows us to identify how structures and mechanisms of symbolic value production are shaped by cultural and institutional contexts. Previous studies have shown that perspectives on arts and culture differ significantly across countries resulting in distinct practices of cultural consumption, production and policy (e.g. Lamont \& Thévenot, 2000; Janssen et al., 2008). Similarly, media systems, including the position and role of newspapers, often vary crossnationally (e.g. Hallin \& Mancini, 2004; Gripsrud \& Weibull, 2010). Most importantly, literary fields and the institutions therein tend to correspond with countries (or sometimes 
language areas). At the same time, all national fields occupy a place in the "world republic of letters" (Casanova, 2004). Thus: literary fields are not completely independent, but they share institutions and probably also ways of producing symbolic value. Moreover, many internationally known authors are read, discussed, and recognized (or not) in different national fields. Hence, comparing countries enables us to compare national fields and therefore validate analyses, but it also allows us to compare if symbolic recognition works in similar ways across national fields. We have selected four countries that each are part of the transnational literary field, yet vary greatly in size and international prestige of their national literary field and literary tradition: France, Germany, the Netherlands and the United States.

Our empirical analysis concerns a content analysis of eight elite newspapers from these four countries in 1955, 1975, 1995 and 2005. For all fiction book authors found in four weeks of newspaper coverage, we retrieved information on the extent to which authors in these articles are recognized by other institutional agents in the literary field. Relying on cluster analysis, we show that in each year three author categories can be found in newspapers: unrecognized, contemporary prestigious, and historically prestigious authors. This suggests that -- despite the emphasis of many recent studies on changes -- the structure of the literary field in terms of symbolic production has been quite stable since the 1950s. Furthermore, our analysis of factors determining membership of these clusters points to the lasting importance of symbolic capital (writing "literature"), but also to the transnational character of institutional recognition.

\section{Symbolic production in the literary field: changes over time}

Although actors working in the domain of arts and culture often emphasize individual talents and accomplishments, the process of attributing and disseminating cultural value is ultimately a social process (e.g. Bourdieu, 1993; Becker, 1982). Bourdieu's (1993) field 
theory has been influential in detailing the multi-layered and relational structure of actors, institutions, and fields all competing to influence symbolic production based upon role and status ("space of positions") as well as actions and statements ("space of position-takings"). In this framework, it is cultural capital - the competences to understand and appreciate legitimated cultural content - that governs decisions on what is "valuable" or prestigious. The symbolic recognition of authors should thus be seen as the outcome of a social process (see also Griswold, 1987; Janssen, 1997, 1998; Sapiro, 2003; Craig \& Dubois, 2010), but how variable or similar has this process been over time? And how has it been modified by the "commercial" or "popular" recognition of authors, or lack thereof, as indicated by, e.g., their sales figures or popularity among "common” readers? Whereas Bourdieu considered economic capital and symbolic capital irreconcilable until the amount of the latter was large enough to transform in it the former, this perspective seems to have become outdated.

Over time, the legitimacy of literary criticism and other cultural institutions is thought to have weakened due to social changes starting in the postwar period (DiMaggio, 1991; Janssen et al., 2011). With the growing social mobility since the 1960 s, the acquisition of the appropriate cultural capital relies less exclusively on the channels of higher education and socialization within dominant social classes. Consequently, ties between positions in the literary field (e.g. that of newspaper critic, literary scholar or publisher) and social positions ("space of habitus") have weakened (DiMaggio, 1991; Griswold, 2008). This development can also be observed for patterns of cultural consumption which have become more individualized and less systematically tied to social backgrounds, making it more difficult for cultural producers and organizations to find their audiences (Bennett et al., 2009). In a similar vein, the almost exclusive focus on "highbrow" arts in newspapers has been abandoned to create space for popular culture (Janssen et al., 2011). At universities, the selection of most consecrated works 
- the canon - has opened up to works relying less on traditional literary norms (e.g. Duell, 2000; Berkers, 2009), while in secondary education teachers have become more receptive to what students like to read at the expense of "canonical" works (Verboord \& Van Rees, 2009). At the same time, artistic values seem to face stronger competition from market forces within cultural fields (e.g. Verboord, 2011) as well as in the media landscape (Gripsrud \& Weibull, 2010; Hellman \& Jaakkola, 2012). What is more, the literary book trade has increasingly adopted a market logic that benefits larger publishing companies, "big books" that have commercial potential, and authors that have been successful early on in their career (Thompson, 2010; Childress, 2011; Franssen \& Kuipers, 2013).

\section{Individual authors and institutional recognition}

How do individual authors fit in wider patterns and processes of institutional recognition and cultural legitimation? The increasing emphasis on organizational contexts in recent scholarship on legitimation has tended to overlook the role of individual artists (authors). Previous studies do, however, highlight the continuous importance of previous institutional recognition for an artists' chance of being considered worthy of inclusion in best-ever lists or encyclopedias later in one's career (e.g. Allen \& Lincoln, 2004; Schmutz \& Faupel, 2010; Braden, 2009). Another line of research has demonstrated how cultural and social capital impact artists' current positions in the cultural field, thereby confirming Bourdieu's hypothesis that actors are positioned in social space in accordance with both their overall volume and relative composition of capital (Anheier \& Gerhards, 1991; Anheier, Gerhards \& Romo, 1995).

More specific analyses of fiction book authors' careers have detailed how the 'space of positions' in the field is related to literary position-takings - not only their writing, but also side-activities, commitments to certain institutions, and engagement with particular social 
themes (Van Rees \& Vermunt, 1996; Janssen, 1998; Ekelund \& Blom, 2002; Verboord, 2003; Craig \& Dubois, 2010; Dubois \& Francois, 2013). Authors' status in the literary field tends to be larger when their activities or relationships accord with elements of literary culture that prominent institutional agents view as signs of distinction. In that sense, authors' practices are institutional by definition as they are continuously filtered through the prism of the dominant logics in the field at the time. Having said this, one cannot dismiss more structural features similar to other social domains inequalities based upon, for instance, descent and gender are also part of the literary field (Tuchman \& Fortin, 1984; Ekelund \& Blom, 2002; Verboord, 2012). Thus, we expect such structural features to affect individual authors' chances to achieve particular forms of institutional recognition. Our analysis will explore this by looking at three author characteristics for which we have information: genre (as an indicator of symbolic capital), gender (as a structural feature) and national background (as an indicator of an author's position in the transnational literary field).

\section{Institutional recognition in the transnational literary field}

There is a clear international dimension to artistic career trajectories and processes of symbolic production as cross-national comparisons of newspapers' art and culture coverage (Janssen et al., 2008; 2011) and publishers' selection criteria (Weber, 2000; Sapiro, 2010), as well as studies of the literary world-system (Casanova, 2004; Moretti, 2013) have reminded us. Despite the consistency that institutional agents such as literary scholars, newspaper critics and award juries often show in value attribution to authors, the disparity in the status of national literatures makes it more difficult for authors of "small" languages to achieve large global literary reputations (Casanova, 2004). This work accords with studies on translations (Heilbron, 1999; Franssen, 2014) and newspaper coverage of authors (Janssen, 2009). 
Yet, a full-grown understanding of how institutional recognition works on a transnational scale is still in the making. The probably most famous study of symbolic value production in the international literary sphere to date, Pascale Casanova's (2004) "World Republic of Letters", is not without controversy as it relies on case studies of selected - highly consecrated - authors and, according to critics, displays a certain bias towards Paris (see D'Haen, 2012: 104ff). Casanova's contribution lies first and foremost in the recognition of the existence of a global literary space in which the circulating cultural capital has different exchange rates in different places. That she identifies France (more specifically Paris) as the undisputed center of this global economy of literary prestige may imply an underestimation of, for instance, the rise of New York in the last decades, as well as the alleged decline of France's cultural importance (Morrison \& Compagnon, 2010). However, it may well be true for the earlier years of our study (cf. Lamont, 1991; Sassoon, 2006). In our analysis, we compare the two global centers, France and the United States, with each other, with Germany - that has a rich literary history yet without a geographical center such as Paris - and the Netherlands - that has a much more marginal position in the global literary field. While we expect considerable overlap between processes and patterns of institutional recognition in these four countries, we also assume that the centers of the literary world show specific dynamics. For instance, they may be more inwardly oriented than more peripheral literary fields (Heilbron, 1999; Janssen, 2009). Moreover, the US, as the "rising center" of the transnational literary field, with a different historical trajectory, may be organized differently than the three European fields. However, as the prestige of the American field increases, European fields may increasingly adopt American logics. Of course, taking the perspective of authors also points to the importance of language areas: authors coming from relatively peripheral countries but writing in a widely spoken language have better chances to find global distribution (Heilbron, 1999; Sapiro, 2010). In addition, linguistic areas often have 
transnational institutions. For instance, many literary awards are not confined to particular nationalities but to specific languages, and, in a similar vein, literary scholars - and their output - are frequently organized around languages rather than national literatures.

\section{Method and data}

To examine how value attributions to authors by newspapers critics and editors are related to those of other agents in the literary field we relied on existing data on the newspaper coverage of fiction book authors between 1955 and 2005 in four countries, which we then complemented with other information on these authors. The newspaper data consist of all newspaper articles on arts and culture published during four randomly sampled constructed weeks ${ }^{\mathrm{i}}$ in the years 1955, 1975, 1995 and 2005 in the newspapers Le Figaro, Le Monde (France), Frankfurter Allgemeine Zeitung, Süddeutsche Zeitung (Germany), NRC Handelsblad, De Volkskrant (Netherlands), the New York Times and the Los Angeles Times (US). ${ }^{\text {ii }}$ This dataset contains 18,088 items. We selected all items on 'literature' and 'fiction writing' (total of 2,899 items). About $87 \%(\mathrm{~N}=2,419)$ of these items concerned a specific author or book of which the author could be identified. Remaining items dealt with publishers, editors or other actors in the literary field and were dropped because of the incomparability of their positions in the field.

For all identified authors we collected further information about their position or status in the literary field when the newspaper article was published. We focused on four different forms of recognition that an author may receive from various institutional agents in the literary field. First, we counted the number of words devoted to each author in encyclopedias published around the same time as the article. Encyclopedias are usually compiled by scholars and indicate long-term literary recognition or prestige (Verboord, 2003). Although we aimed for encyclopedias published in the year of our sample newspapers, we were severely limited 
by the restricted choice in encyclopedias and thus sometimes had to use slightly older reference works (see Appendix A2). Since compilation of encyclopedias and lexicons is a task that takes up years, (cf. Van Rees, 1983; 1987; Rosengren, 1998), and is relatively immune to contemporary criticism, we do not think this is a major problem.

Second, for all authors in the dataset, we counted the number of literary prizes they won in the twenty years before publication of the article. ${ }^{\text {iii }}$ We consider awards an indicator of short-term literary recognition or prestige (English, 2005). We collected data on awards and prizes from the newspaper countries of our sample newspapers, from other countries in the same language area, international prizes open to all language areas (e.g. Nobel Prize for literature) and prizes from other dominant language areas such as Spanish, Italian, Portuguese, etc. In compiling these lists, we mainly relied on Internet sources (see Appendix A1).

Third, for each author we counted the number of books that made the bestseller lists in the ten years preceding publication of the newspaper article. We take this to indicate authors' commercial success (or 'popular recognition' in terms of Allen \& Lincoln, 2004). We used historical bestseller lists from L'Express (France), Der Spiegel (Germany), Haagse Post, Libris, CPNB (the Netherlands) and the New York Times (US) (see Appendix A3). Note that for literary awards we took a longer time frame (20 years) than for bestseller list success (10 years), as we expect literary prestige to resonate longer than commercial success.

Fourth, for each author/book we recorded the publisher and assessed its size and literary prestige. Publishers' size was established by counting how many authors/books published by a certain publisher were covered in the newspapers of the sample year (restricted to the home country of the publisher). Publishers' literary prestige was measured by counting the number of national literary prizes authors in the publisher's catalogue had won in the previous 10 years; and the number of Nobel prize winners of the past 20 years (to account for publishers specialized in foreign literature). We already had information on national literary 
prize winner information (see above). Data on publishers of Nobel laureates was collected additionally for each country.

All these indicators of institutional recognition are both longitudinal and crossnational. We have tried to optimize comparability by selecting, as much as possible, longrunning indicators that are similar across countries. However, the cross-national comparability of our data is difficult to standardize. While all legitimizing institutions exist in our sample countries (with the exception of bestseller lists in Europe in the 1950s), the position of the countries, and languages spoken in these countries, within the international literary field varied greatly (cf. Casanova, 2004; Heilbron, 1999). We therefore distinguish between indicators which signal an international recognition versus indicators which reflect an author's recognition in a more restricted, local domain (either a specific national field or a specific language area). For literary awards and encyclopedias we chose to use language as a distinction key since many awards are organized by language area and many encyclopedias tend to pay more attention to authors writing in the encyclopedia's source language. This is not to say that distinguishing "global" or "international" from "local" recognition could not have been done (better) using nationality as the splitting criterion. However, for now restrictions of the data - for many countries we have (a) low numbers of authors, and (b) little information on awards and encyclopedias - render the present strategy more viable. Bestseller lists are arranged by country of the author. Finally, all this information about the recognition of authors was merged with the newspaper data (see Appendix A4 for details).

\section{Results}

To assess the relative importance of the four forms of institutional recognition, and how these forms of recognition are related, we performed a separate cluster analysis for each year (for all four countries). The analyses contain the amount of prizes won, the number of bestseller 
hits and the number of words in encyclopedias (all in domestic and international variants) and the size and prestige of the publisher. The former four variables were modeled as categorical variables $;{ }^{\text {iv }}$ the latter four as continuous variables. Finally, we added dummy variable recording whether the author was alive at the time of publication.

Table 1: Trends in author cluster distributions $1955-2005$ by country

\begin{tabular}{l|lllll}
\hline $\begin{array}{l}\text { Clusters } \\
\text { (characteristics in italics) }\end{array}$ & & 1955 & 1975 & 1995 & 2005 \\
\hline 1 Unrecognized & Overall & $57.1 \%$ & $54.5 \%$ & $40.2 \%$ & $41.7 \%$ \\
- No LP/BE & FRA & $32.7 \%$ & $54.1 \%$ & $42.2 \%$ & $46.8 \%$ \\
- Low EN/PUB & GER & $39.3 \%$ & $38.5 \%$ & $30.9 \%$ & $36.0 \%$ \\
- Living authors & NET & $50.8 \%$ & $48.9 \%$ & $30.7 \%$ & $28.1 \%$ \\
& US & $69.9 \%$ & $72.6 \%$ & $57.1 \%$ & $60.1 \%$ \\
\hline 2 Contemporary prestigious & Overall & $24.2 \%$ & $25.0 \%$ & $37.4 \%$ & $38.9 \%$ \\
- High LP/BE & FRA & $48.1 \%$ & $32.0 \%$ & $35.4 \%$ & $39.2 \%$ \\
- Medium EN/PUB & GER & $21.4 \%$ & $26.2 \%$ & $40.1 \%$ & $35.5 \%$ \\
- Living authors & NET & $26.2 \%$ & $30.0 \%$ & $45.8 \%$ & $46.5 \%$ \\
& US & $18.7 \%$ & $15.1 \%$ & $29.1 \%$ & $32.7 \%$ \\
\hline 3 Historical prestigious & Overall & $18.6 \%$ & $20.5 \%$ & $22.4 \%$ & $19.4 \%$ \\
- Medium LP/BE & FRA & $19.2 \%$ & $13.9 \%$ & $22.4 \%$ & $14.0 \%$ \\
- High EN/PUB & GER & $39.3 \%$ & $35.4 \%$ & $29.0 \%$ & $28.4 \%$ \\
- Often deceased & NET & $23.1 \%$ & $21.1 \%$ & $23.5 \%$ & $25.3 \%$ \\
& US & $11.5 \%$ & $12.3 \%$ & $13.7 \%$ & $7.1 \%$ \\
\hline Chi-Square & & $49.3 * * *$ & $45.9 * * *$ & $38.6 * * *$ & $59.5 * * *$ \\
\hline
\end{tabular}

Table 1 shows the outcomes of the cluster analysis. The clusters we found are remarkably consistent over time. For each year, roughly the same three clusters emerge: first, a cluster that consists of authors who have never won literary prizes, have not enjoyed bestseller list success, have received very limited attention in encyclopedias and were published at small and not very prestigious publishers. We call this group the "unrecognized". The second cluster is formed by authors who have won prizes, have made the bestseller lists, and to some extent have also received sizable entrances in encyclopedias and have been published by respectable publishers. They consist largely of living authors, which is why we call them "contemporary prestigious". The third and last cluster also contains authors with considerable institutional recognition, albeit this is slightly differently structured. Here, authors have relatively larger encyclopedia entrances, yet are somewhat less likely to have won prizes or 
written bestsellers. Most of the authors in this category are deceased. In other words, this cluster seems to comprise particularly the authors holding more "historical prestige". The lack of awards and bestsellers therefore reflect changes in the field: the explosion of literary prizes, as well as the expansion of bestseller lists during the time of our study.

The consistency of clusters has a number of important theoretical implications. For one thing, it suggests that various forms of institutional recognition are considerably interwoven. While this may have been expected for winning prizes and entering encyclopedias, the correlation with bestseller list success is more surprising. Of course, this result applies to authors who already have been selected for newspaper coverage. The bestseller list authors we encountered may not be representative for the whole population of bestselling authors (with often contains highly popular, "illegitimate" books). Moreover, we find no distinctions between local and international recognition. Institutional recognition appears to be quite transnational in nature as local and international recognition show highly similar patterns. Finally, the number and nature of clusters does not change over time, implying that the underlying structure of forms of recognition has not become more or less complex over time. This comes as somewhat of a surprise, since the proliferation of literary awards and the rise of bestseller lists are trends that have arguably changed the field (e.g. Thompson, 2010; Collins, 2010). While these forms of institutional recognition have become more prominent, this has not led to the emergence of distinctive new patterns of recognition in newspapers' literary coverage.

All these findings suggest that the overall institutional logics underlying the selection/evaluation of fiction book authors in elite newspapers has not changed that much. That is to say, the way in which elite newspaper critics and editors incorporate evaluations of other agents in the field - appears to have stayed the same. First, there are authors who make it into newspapers, but are not recognized (yet) by other institutions. Examples are Enid 
Blyton (NRC, 1955), Olivier Renaudin (Le Monde, 1975), Julia Alvarez (LAT, 1995), and Felicitas Hoppe, (FAZ, 2005). Second, there is a group of contemporary authors who are more or less universally recognized: they receive awards, publish at renowned publishers, are listed in encyclopedias and make bestseller lists. In other words: we find no contradiction between different forms of recognition, or between 'economic' and cultural capital. Examples here are Hervé Bazin (NYT, 1955), Gunter Grass (FAZ, 1975), Peter Ackroyd (LAT, 1995), and Amitav Ghosh $(N R C, 2005)$. The third group of authors is characterized by more long-term recognition, which is also rooted in more traditional cultural capital. Examples are Victor Hugo (Le Monde, 1955), Cesare Pavese (FAZ, 1975), Henry David Thoreau (NYT, 1995), and Pablo Neruda (SZ, 2005).

To what extent is this pattern manifest over time and across countries? We first describe the overall changes through time (see again Table 1). In 1955, unrecognized authors received about $57 \%$ of all literary coverage in newspapers. Another $24 \%$ of the attention was paid to contemporary prestigious authors, leaving almost $19 \%$ to the historical prestigious authors. In the course of time, unrecognized authors became less omnipresent in newspapers a transition which took place particularly in the period between 1975 and 1995. Still, these authors continued to be the largest group (around 40\%). Contemporary prestigious authors took most of the share that the unrecognized lost: they grew from $24 \%$ to almost $39 \%$ in 2005 . Historical prestigious authors remained the smallest group throughout, although their 2005 proportion is slightly larger than their share in 1955 (19.4\% vs. 18.6\%). Consideration that newspapers in their cultural gatekeeping role take the first pick out of the new supply of books (cf. Janssen, 1997), and in the journalistic role primarily follow the news, this continuous focus on deceased, often classic authors (e.g. Baudelaire, Goethe, but also $20^{\text {th }}$ century authors such as Italo Svevo, Ivo Andrić) is striking. 
We note important differences among countries, however. Compared to the European newspapers, American newspapers devote significantly more attention to unrecognized authors and less to contemporary or historically prestigious authors. Even in 2005 the space given to the former group amounts to $60 \%$, while historically important authors comprise just $7 \%$ of their coverage. European newspapers show a different picture, though not always consistently. In Dutch newspapers, the percentage of historical prestigious authors lies at a fairly constant 21-25\%, while the high percentage of unrecognized authors in 1955 and 1975 (around 50\%) is outbalanced by a larger group of contemporary prestigious authors in the last two sample years (45-46\%). In Germany this latter group also increases strongly after 1995, but here it is at the expense of the historical prestigious authors, who took up more than a third of all book coverage in 1955 and 1975. Finally, France shows one of the most stable cluster distributions of all countries, if not for 1955. That year, contemporary prestigious authors comprise an unprecedented $48 \%$ of all authors discussed in the sampled newspapers. Put in a longitudinal perspective, their domination edges out unrecognized authors rather than historical prestigious authors. Possibly this is due to an already quite evolved literary field (including many literary awards), in combination with the strong position of France in the transnational field, at that time.

\section{Individual authors and institutional recognition}

Having mapped the dominant ways institutional recognitions are structured across time, we now examine what author characteristics predict membership of these clusters. Thus, whereas our first analysis disclosed the space of positions of authors in the field (as attributed by institutions in the field), we next connect this to the space of habitus - the system of dispositions based upon capital and social background characteristics (Bourdieu, 1993). More specifically, our analysis explores who gets recognized, in terms of nationality, gender and, as 
an indicator of cultural capital, the predominant literary genre of the author. ${ }^{\mathrm{v}}$ The genre was coded in three categories: literary, mainstream and popular fiction, based upon career descriptions in literary encyclopedias and online sources. Mainstream was the default category; an author was coded as "literary" when we found explicit references to a highbrow literary career (including poetry, short stories, essays). Popular fiction authors are those who are explicitly labeled as writing thrillers, detectives, romance, or science-fiction/fantasy books.

Our study of institutional recognition centers on elite newspapers which, as was described earlier, are rooted in national media systems and may have changed their editorial policies and journalistic practices over time. Possibly, the way authors are selected and discussed is related to how newspapers bring cultural news: in certain types of articles, focusing on certain content, etc. To rule out the possibility that such newspaper level factors affect the attribution of authors to clusters we introduce two control variables. The first one is the country of the newspaper (via four dummy variables). The second is the type of article in which the author was discussed. For this purpose, we inductively created a new variable indicating the formal traits of every coded newspaper article with a Principal Components Analysis for Categorical Data (CATPCA) for six variables: Type of article (six categories: interview; (p)review; announcement, news, background, other); Article content (six categories: product; award/reception; career; business/juridical/policy; human interest/controversy; other); Type of section in which the article appeared (four categories: general/economic; arts general; books; life style and other); Type of author article (four categories: employee newspaper; freelancer; press agency; unknown); Number of articles by author article in sampled newspaper editions (five categories: no name known; 1 article; 2-3; 4-10; more than 10); Number of illustrations in article (three categories: 0 ; 1 ; more than 1). We asked for a default two-dimensional solution. The total eigenvalue was 4.169 meaning 
that the analysis was only able to explain $4.16 \%$ of the total variance. The reliability of the first dimension was satisfactory (Cronbach's alpha=.789). Interpretation of this dimension shows a range from the traditional newspaper article (likely to be: a review article, about a product, positioned in general parts of the newspaper, written by unknown journalists or press agencies, not illustrated) to a more progressive format (likely to be: another type of article, having another subject than product, positioned in book section, written by newspaper journalists).

Table 2: Multinomial logistic regression of cluster membership per year

\begin{tabular}{|c|c|c|c|c|}
\hline & 1955 & 1975 & 1995 & 2005 \\
\hline \multicolumn{5}{|l|}{ Cluster 1 Unrecognized } \\
\hline & reference & reference & reference & reference \\
\hline \multicolumn{5}{|l|}{ Cluster 2 Cont. prestigious } \\
\hline Foreign author (vs. domestic) & $2.815 * *$ & 1.364 & $1.859 * *$ & $2.157 * * *$ \\
\hline Male author (vs. female) & 1.705 & $2.791 * *$ & $1.435 \sim$ & 1.343 \\
\hline Literary author & $3.968 * *$ & $3.475 * * *$ & $1.762 *$ & $2.330 * * *$ \\
\hline Mainstream author & 1.723 & $0.339 \sim$ & 0.450 & $0.191 *$ \\
\hline Popular author & Ref & Ref & Ref & Ref \\
\hline French newspaper & $4.833 * * *$ & $1.790 \sim$ & 1.163 & 1.151 \\
\hline German newspaper & 1.390 & $1.862 \sim$ & $1.724 *$ & 1.102 \\
\hline Dutch newspaper & 1.410 & $2.357 * *$ & $2.425 * *$ & $1.770 *$ \\
\hline American newspaper & Ref & Ref & Ref & Ref \\
\hline Form article less traditional & 1.097 & $1.552 * *$ & $1.384 * *$ & $1.557 * * *$ \\
\hline \multicolumn{5}{|l|}{ Cluster 3 Historical prestige } \\
\hline Foreign author (vs. domestic) & $6.069 * * *$ & 1.500 & $1.728 *$ & $2.266 * *$ \\
\hline Male author (vs. female) & 1.626 & $1.829 \sim$ & $2.225 * *$ & $3.396 * * *$ \\
\hline Literary author & 2.100 & $3.487 * * *$ & $2.509 * *$ & $2.592 * *$ \\
\hline Mainstream author & $3.124 \sim$ & 1.174 & 1.652 & 0.802 \\
\hline Popular author & Ref & Ref & Ref & Ref \\
\hline French newspaper & $2.784 \sim$ & 0.819 & 1.249 & 1.603 \\
\hline German newspaper & $3.821 * * *$ & $2.918 * *$ & $2.114 *$ & $3.317 * *$ \\
\hline Dutch newspaper & 1.251 & 1.602 & $2.196 *$ & $3.821 * * *$ \\
\hline American newspaper & Ref & Ref & Ref & Ref \\
\hline Form article less traditional & $1.674 * *$ & $1.667 * * *$ & $1.844 * * *$ & $1.787 * * *$ \\
\hline $\mathrm{N}$ & 382 & 488 & 781 & 768 \\
\hline-2 log likelihood & $534.3 * * *$ & $686.5 * * *$ & $1221.6 * * *$ & $1146.4 * * *$ \\
\hline Nagelkerke $\mathrm{R}^{2}$ & $30.1 \%$ & $27.7 \%$ & $16.1 \%$ & $23.2 \%$ \\
\hline
\end{tabular}

Controlled for whether author writes in language of one of the newspapers or not. 
Table 2 shows the results of a series of multinomial logistic regression analyses of authors' cluster membership in the four sample years. The cluster of the unrecognized authors is the reference category. Inspection of the Nagelkerke $\mathrm{R}^{2}$ suggests that the modeled variables best predicted membership in $1955(30.1 \%)$. The level of explained variance decreases to $16.1 \%$ in 1995 and rises again to $23.2 \%$ in 2005 .

Overall, the difference between author characteristics in the group of unrecognized and contemporary prestigious authors seems to become somewhat smaller between 1955 and 2005 - particularly in terms of country of origin and genre. The difference between unrecognized and historical prestigious authors seems to have increased slightly with regards to gender.

With the exception of 1975, foreign authors have continuously been more likely than domestic authors to be contemporary or historically prestigious authors. Since domestic authors comprise a relatively large proportion of the total newspaper coverage (Janssen, 2009), elite newspapers necessarily apply much less stringent selection criteria (in terms of institutional prestige) for local than for foreign authors. Comparing 1955 and 2005 suggests that the mentioned likelihoods of foreign authors falling into the more prestigious clusters have decreased. Yet, these trends appear to be far from stable, as the odds for 1975 are not significant and those of 1995 are below the level of 2005 .

For gender, the results are less decisive. Whilst the direction of the effects is uniform male authors are more likely to belong to the more prestigious clusters - not all effects are significant, and differences occur between contemporary and historically prestigious authors. In 1955, no differences existed between clusters in terms of gender distribution. Twenty years onward, the odds for male authors to be contemporary prestigious were considerably higher 
than for females, while for historical prestige the difference was negligible. But whereas the gap has been closing for the former, it has been widening for the latter.

Writing literary fiction generally offers an easier route towards institutional recognition than mainstream fiction and popular fiction. However, 1955 shows a curious exception: here, authors of mainstream fiction receive more recognition. A possible explanation is the less developed literary field at that time, combined with the limited amount of popular authors appearing in the newspapers. Depending on which year to start, the likelihood of literary authors being more historically prestigious than popular authors seems therefore larger in 2005 if compared to 1955, but smaller than in 1975. The odds of belonging to the cluster of contemporary prestigious authors declines slightly after 1975, suggesting that here the advantage of literary authors is decreasing.

Traditional markers of symbolic capital and structural inequality thus still seem to impact how literary worth is attributed. This is true while taking into account that countries and form aspects of newspapers may differ. As such, the analysis also contributes to our understanding of cross-national variations. Clearly, European newspapers in general were more likely to devote attention to more prestigious clusters- in other words: European newspapers are more oriented towards "consecrated" authors. This confirms the findings of Table 1, but this time controlling for author and article characteristics. Over time, French newspapers have come to resemble US newspapers in their emphasis on unrecognized authors. At the other end of the spectrum, Dutch and German newspapers pay significantly more attention to historical prestigious authors: the Netherlands only in 1995 and 2005, Germany during the whole period. 


\section{Conclusion and discussion}

In recent years, the legitimacy of cultural institutions is thought to have weakened due to social changes starting in the postwar period (DiMaggio, 1991; Janssen et al., 2011). While various explanations have been proposed -- e.g. growing social mobility leading to more omnivorous taste patterns among audiences, decline of higher education, increasing commercialization in the arts (Peterson \& Kern, 1996; Van Eijck \& Knulst, 2005) -- we argue that institutional consensus is among the prerequisites for cultural legitimation and, as such, worthwhile to study from a longitudinal perspective.

In this paper, we examined whether and how patterns and structures of institutional recognition in the literary field - as seen in elite newspapers' literary coverage - , have changed over time. More specifically, our analysis is concerned with how the value attributions to fiction book authors by newspaper critics and editors accord with those of other agents in the literary field (e.g. juries of literary prizes, publishers) in the period 1955-2005. In addition, we add a cross-national layer on existing work by comparing institutions from France, Germany, the Netherlands, and the United States. Hence, our study contributes to Casanova (2004), Kuipers (2011) and other scholars of global and transnational cultural production in detailing how national literary fields are interconnected and intertwined.

The results indicate that the institutional logics governing newspapers' selection of authors has not changed that much since the 1950s. Consistently, institutional recognitions are structured around three understandings of literary worth. Elite newspapers' institutional position manifests itself in the following three clusters of authors: the unrecognized, the contemporary prestigious (who recently won literary awards and/or were listed in bestseller lists), and the historical prestigious (who won literary awards and/or are discussed in literary encyclopedias). Over time, the latter group continues to comprise about $20 \%$ of the coverage. Unrecognized authors - those without any form of recognition - lose importance (from about 
three fifth to two fifth) at the gain of contemporary prestigious authors (from one fifth to almost two fifth).

These patterns differ significantly across countries, however. In general, the European countries show a much stronger connection to more highbrow forms of institutional recognition than the US. Throughout the period under investigation, American newspapers allocate more than half of their attention to authors with little or no institutional prestige neither artistic nor commercial. This is in accordance with findings on national "cultural repertoires" (cf. Lamont and Thevenot, 2000), suggesting that the US is generally less hierarchical than European countries. Amongst the European newspapers particularly German and Dutch papers select many historical prestigious authors. Even in 2005 about a quarter of all discussed authors belong to this category. Both countries are more marginal in the transnational literary field, and possibly their lack of international literary prestige and impact contributes to their relatively limited focus on contemporary developments.

How institutional agents establish regimes of literary worth obviously affects the recognition individual authors may achieve. Therefore, the second part of our analysis consisted of assessing which types of authors were more likely to be considered for which type of recognition. We find that symbolic capital (writing "literature") remains important for recognition, though its peak appeared to have been in the 1970s. Foreign authors are more likely to fall in the category of prestigious authors than local authors. This confirms the existence of a transnational literary field in which institutions have consensual beliefs on the value of particular top authors. At the same time, we observe country differences as the US and France tend to pay relatively more attention to domestic authors, which seems to point at their importance in this global field. Since their literatures have high status within the cultural world-system (Casanova, 2004; Janssen, 2009), these countries can afford to deviate slightly from the overall regime. An alternative interpretation would be that more domestic authors 
are being published in the US and France. However, inspection of the figures provided by Janssen (2009: 355) suggests that while this could be true for the US, the literary production in Germany is actually higher than in France.

In sum, literary fields in the studied countries - using elite newspaper as our baseline show little divergence. Trends of commercialization, more omnivorous participation, or increasing institutional polarization are not very clearly reflected in the patterns of institutional recognition we find. Moreover, we find limited differences between national literary fields, although the US and -perhaps more surprisingly - France appear to be slightly more open or "democratic" in their attention to contemporary authors. Along with the stronger historical focus of German and Dutch newspapers, we tentatively interpret this as an effect of the position in the transnational literary field: newspapers in more central countries are more interested in "new" authors, whereas newspapers in less influential countries devote more attention to the "classics". However, elite newspapers in each country have continued to rely on the value attributions of other institutional agents in the literary field, in a manner which proves to be quite robust over time. Whether this is despite or because of the prominence of highbrow culture -- such as literary fiction -- has shrunk in elite newspapers (Janssen et al., 2011) remains to be seen.

There are some limitations to our study, of course, that need to be mentioned. Our choice to analyze a fifty year period comes at the price of not having all information available that would be ideal. For instance, we did not always have access to the complete content of the articles, and for authors from different origin countries than our four countries of focus, we did not consider local bestseller lists, encyclopedias, and literary awards. Also, for older, less famous authors it has proved difficult to find detailed data on careers (e.g. education as an indicator of cultural capital), institutional recognition or contacts with others in the field. What is more, establishing trends requires a certain consistency in available measurements, 
but we acknowledge that cultural fields have evolved in the past fifty years (e.g. the proliferation of bestseller lists). Our results could be affected by such changes, albeit probably more for 1955 than for later years. Furthermore, like in most cultural fields, we ran into the issue of many individuals with few observations (and it was not possible to increase the sample size since we worked with existing (newspaper) data. Because of this problem many previous studies focused on artists who already had some form of success or recognition (e.g. Allen \& Lincoln, 2004; Braden, 2009; Dubois \& Francois, 2013). While we see the merit of such approaches, at the same time we believe that our study of newspaper classifications makes an important contribution: it clearly unveils the role of the unrecognized in legitimation processes. Literary fields continue to be battlegrounds for recognition in which large portions of the participants remain relatively unnoticed yet are the reference groups to which the worthy are compared.

\section{Article Notes}

This research was financially supported by the Dutch Science Foundation (NWO) funded VICI-project Cultural Classification Systems in Transition (NWO-project 277-45-001).

\section{Notes}

i. The sampling method of the constructed week is a specific form of stratified sampling: every week day is represented equally, but not from the same weeks, to avoid bias towards particularities of one news week (Riffe et al., 1993). So there might be a Monday edition from week one, a Tuesday edition from week five, etc. In our case, we constructed four weeks, one for each quarter of the year to account for seasonal biases.

ii. The year 2005 actually concerned the latter half of 2004 and the first half of 2005. For the Los Angeles Times, only three constructed weeks were sampled. Magazines were left out of the analyses. The particular years were chosen for the following reasons: (1) since the original project aimed to map post-War transitions in classification systems, the starting point was the 1950s; (2) decade spreads were the result of balancing (a) the aim to cover a substantial historical period, (b) the level of detail in the analysis of individual newspapers, and (c) time/financial restrictions; (3) the data were collected in 2005/2006.

iii. For 1955, we took the period 1940-1955, since not many awards already existed before this time.

iv. Bestseller lists were recoded as $1=0 ; 2=1 ; 3=2-3 ; 4=4-10 ; 5=10+$. Literary prizes were recoded as $1=0 ; 2=1 ; 3=2-3 ; 4=3+$. 
v. Note that the number of characteristics is somewhat limited because of the difficulty of finding background information on 1000+ authors from three countries for a period dating back to the 1950 s.

\section{Author biographies}

Marc Verboord is Associate Professor in the department of Media and Communication at Erasmus University Rotterdam and ERMeCC (Erasmus Research Centre in Media, Communication and Culture). His research focuses on cultural consumption patterns, cultural globalization, classification of cultural products, and the Internet's impact on the social valuation of cultural products.

Giselinde Kuipers is Professor of Cultural Sociology at the University of Amsterdam and Director of the Cultural Sociology Program group at this University. She has published widely on the sociology of popular culture, media, humor, beauty, cultural globalization and comparative sociology, and is the author of Good Humor, Bad Taste: A Sociology of the Joke (Mouton de Gruyter, 2006, revised edition 2015). She is affiliated with the Cultural Classification Systems in Transition project at Erasmus University Rotterdam. Currently, she is the principal investigator in an ERC-funded research project on the comparative sociology of beauty.

Susanne Janssen is Professor of Sociology of Media and Culture at Erasmus University Rotterdam. She has published widely on the agents and institutions involved in the creation, dissemination and valuation of literature and other art forms. Her current research focuses on changes and continuities in the classification of culture; the social and cultural significance of popular music heritage; processes, structures and impacts of cultural globalization; and the production and consumption of online media content. 


\section{References}

Allen, M.P., Lincoln, A.E. (2004). Critical Discourse and the Cultural Consecration of American Films. Social Forces 82(3): 871-894.

Anheier, H.K., Gerhards, J. (1991). Literary Myths and Social Structure. Social Forces 69(3): 811-830.

Anheier, H.K., Gerhards, J. \& Romo, F.P. (1995). Forms of capital and social structure in cultural fields: Examining Bourdieu's social topography. American Journal of Sociology 100: 859-903.

Baumann, S. (2007). Hollywood Highbrow. From Entertainment to Art. Princeton, NY: Princeton University Press.

Baumann, S., Dowd, T.J., Janssen, S. (Eds.) (2009). Classifying culture: Agents, structures, processes. Special Issue Poetics 37(4): 295-398.

Becker, Howard S. (1982). Art Worlds. University of California Press, Berkeley.

Berkers, P. (2009). Ethnic boundaries in national literary histories: Classification of ethnic minority fiction authors in American, Dutch and German anthologies and literary history books, 1978-2006. Poetics 37: 419-438.

Braden, L. (2009). From the Armory to academia: Careers and reputations of early modern artists in the United States. Poetics 37: 439-455.

Bourdieu, P. (1980). The production of belief: Contribution to an economy of symbolic goods. Media, Culture and Society 2: 261-293.

Bourdieu, P. (1984). Distinction. Harvard University Press, Cambridge, MA.

Bourdieu, P. (1993). The Field of Cultural Production. New York: Columbia University Press.

Casanova, P. (2004). The World Republic of Letters. Cambridge, MA: Harvest University Press.

Childress, C.C. (2011). Evolutions in the literary field: The co-constitutive forces of institutions, cognitions, and networks. Historical Social Research 36: 115-135.

Collins, J. (2010). Bring on the Books for Everybody: How Literary Culture Became Popular Culture. Durham, NC: Duke University Press

Craig, A. \& Dubois, S. (2010). Between art and money: The social space of public readings in contemporary poetry economics and careers. Poetics 38: 441-460.

Curran, J. (2000). Literary Editors, Social Networks and Cultural Tradition. In: J. Curran (ed.), Media Organizations in Society, 215-239. London: Arnold. 
D'Haen, T. (2012). The Routledge Concise History of World Literature. London: Routledge.

DiMaggio, P. (1982). Cultural entrepreneurship in nineteenth-century Boston. Media, Culture \& Society 4: 33-55, 303-322.

DiMaggio, P. (1987). Classification in Art. American Sociological Review 52: 440-455.

DiMaggio, P. (1991). Social Structure, Institutions, and Cultural Goods: The Case of the United States. In: P. Bourdieu \& J.S. Coleman (Eds.): Social Theory for a Changing Society (pp.133-155). Boulder, Colorado: Westview Press.

DiMaggio, P. (1992). Cultural boundaries and structural change. In: M. Lamont \& M. Fournier (Eds.), Cultivating Differences (pp.21-57). Chicago: University of Chicago Press.

Dubois, S. \& François, P. (2013). Career paths and hierarchies in the pure pole of the literary field: The case of contemporary poetry. Poetics 41: 501-523.

Ekelund, B.G. \& Blom, M.B. (Eds.) (2002) Literary generations and social authority: A study of US prose-fiction debut writers, 1940-2000. Special Issue Poetics 30(5/6): 299-402.

English, J. F. (2005). The Economy of Prestige. Prizes, Awards and the Circulation of Cultural Value. Harvard University Press, Cambridge, MA.

Franssen, T. (2014). Book translations and the autonomy of genre subfields in the Dutch literary field, 1981-2009. Accepted for publication in Translation Studies.

Franssen, T. \& Kuipers, G. (2013). Coping with uncertainty, abundance and strife: Decisionmaking processes of Dutch acquisition editors in the global market for translations. Poetics 41: 48-74.

Gripsrud, J. \& Weibull, J. (Eds.) (2010). Media, Markets \& Public Spheres. European Media at the Crossroads. Bristol/Chicago: Intellect.

Griswold, W. (1987). The Fabrication of Meaning: Literary Interpretation in the United States, Great Britain, and the West Indies. American Journal of Sociology 92:10771117.

Griswold, W. (2008). Regionalism and the Reading Class. Chicago: University of Chicago Press.

Hallin, D. \& Mancini, P. (2004). Comparing Media Systems. Cambridge: Cambridge University Press.

Heilbron, J. (1999). Towards a sociology of translation. Book translations as a cultural worldsystem. European Journal of Social Theory 2(4): 429-444.

Hellman, H. \& Jaakkola, M. (2012). From aesthetes to reporters: The paradigm shift in arts journalism in Finland. Journalism 13: 783-801. 
Janssen, S. (1997). Reviewing as a Social Practice: Institutional Constraints on Critics' Attention for Contemporary Fiction. Poetics 24: 275-97.

Janssen, S. (1998). Side-roads to success: The effect of sideline activities on the status of writers. Poetics 25: 265-280.

Janssen, S. (2009). Foreign literature in national media. Arcadia 44: 352-374.

Janssen, S., Kuipers, G., Verboord, M. (2008). Cultural Globalization and Arts Journalism. American Sociological Review 73(5): 719-740.

Janssen, S., Verboord, M., Kuipers, G. (2011). Comparing Cultural Classification. High and popular arts in European and US elite newspapers, 1955-2005. Kölner Zeitschrift für Soziologie und Sozialpsychologie (KZfSS) 63: 139-168.

Johnson, C., T. Dowd \& C.L. Ridgeway (2006). Legitimacy as a social process. Annual Review of Sociology 32: 53-78.

Kersten, A. \& Bielby, D. (2012). Film discourse on the praised and the acclaimed. Reviewing criteria in the United States and United Kingdom. Popular Communication 10: 183200.

Kristensen, Nete Nørgaard. 2010. The historical transformation of cultural journalism. Northern Lights: Film \& Media Studies Yearbook 8(1): 69-92.

Kuipers, G. (2011). Cultural globalization as the emergence of a transnational field: Transnational television and national media landscapes in four European countries. American Behavioral Scientist 55: 541-557.

Lamont, Michèle. 1991. Money, Morals, \& Manners. The Culture of the French and the American Upper-Middle Class. Chicago: University of Chicago Press.

Lamont, M., Thévenot, L. (Eds.) (2000). Rethinking Comparative Cultural Sociology. Repertoires of Evaluation in France and the United States. Cambridge, MA: Cambridge University Press.

Moretti, F. (2013). Distant Reading. London: Verso.

Morrison, D. \& Compagnon, A. (2010). The Death of French Culture. Cambridge: Polity.

Peterson, R.A. \& Kern, R.M. (1996). Changing Highbrow Taste: From Snob to Omnivore. American Sociological Review 61: 900-907.

Riffe, D., Aust, C.F. \& Lacy, S.R. (1993). The effectiveness of random, consecutive day and constructed week samples in newspaper content analysis. Journalism Quarterly 70: 133-139.

Rosengren, K. E. (1998). The climate of literature: A sea change? Poetics 25(5): 311-326

Sapiro, G. (2003). The literary field between the state and the market. Poetics 31: 441- 
464.

Sapiro, G. (2010). Globalization and cultural diversity in the book market: The case of literary translations in the US and in France. Poetics 38: 419-439.

Sassoon, D. (2006). The Culture of the Europeans. From 1800 to the Present. Harper Press, London.

Schmutz, V. \& Faupel, A. (2010). Gender and cultural consecration in popular music. Social Forces 89(2): 685-708.

Shrum, W. (1991). Critics and Publics: Cultural Mediation in Highbrow and Popular Performing Arts. American Journal of Sociology 97: 347-375.

Street, J. (2005). 'Showbusiness of a Serious Kind': A Cultural Politics of the Arts Prize. Media, Culture \& Society 27(6): 819-840.

Thompson, J.B. (2010). Merchants of Culture. The Publishing Business in the Twenty-First Century. Cambridge, UK: Polity Press.

Thornton, P. (2004). Markets From Culture. Institutional Logics and Organizational Decisions in Higher Education Publishing. Stanford: Stanford University Press.

Tuchman, G. \& Fortin, N.E. (1984). Fame and Misfortune: Edging Women Out of the Great Literary Tradition. American Journal of Sociology 90(1): 72-96.

Van Eijck, K. and Knulst, W. (2005). No more need for snobbism: Highbrow cultural participation in a taste democracy. European Sociological Review 21: 513-28.

Van Rees, C.J. (1983). How a literary work becomes a masterpiece: On the threefold selection practiced by literary criticism. Poetics 12: 397-417.

Van Rees, C.J. (1987). How reviewers reach consensus on the value of literary works. Poetics 16: 275-294.

Van Rees, K. \& Dorleijn, G.J. (2001). The eighteenth-century literary field in Western Europe: The interdependence of material and symbolic production and consumption. Poetics 28: 331-348.

Van Rees, C.J. \& Vermunt, J. (1996). Event history analysis of authors' reputation: effects of critics' attention on debutants' careers. Poetics 23: 317-333.

Verboord, M. (2003). Classification of authors by literary prestige. Poetics 31(3-4): 259-281.

Verboord, M. (2012). Female bestsellers: A cross-national study of gender inequality and the popular-highbrow culture divide in fiction book production, 1960-2009. European Journal of Communication 27: 395-409.

Verboord, M. (2011). Market logic and cultural consecration in French, German and American bestseller lists, 1970-2007. Poetics 39: 290-315. 
Verboord, M., Van Rees, K. (2009). Literary Education Curriculum and Institutional Contexts. Textbook Content and Teachers' Textbook Usage in Dutch Literary Education, 1968-2000. Poetics 37(1): 74-97.

Weber, D. (2000). Culture of Commerce? Symbolic Boundaries in French and American Book Publishing. In: M. Lamont \& L. Thévenot (Eds.): Rethinking Comparative Cultural Sociology (pp.127-147). Cambridge, MA: Cambridge University Press. 


\section{Appendices}

\section{Table A1: List of literary awards used per country}

\begin{tabular}{|c|c|c|}
\hline & National & Names of awards \\
\hline English & United States & 2: Pulitzer Prize*; National Book Award*; \\
\hline \multirow[t]{11}{*}{ language } & & 1: National Book Critics Circle Award*; PEN/Faulkner Award*; Howells Medal*; Los \\
\hline & & Angeles Times Book Prize*; National Jewish Book Award; American Academy of Arts and \\
\hline & & Letters Gold Medal; Hemingway/PEN Award; Dos Passos Prize; Janet Heidinger Kafka Prize; \\
\hline & United Kingdom & 2: Booker Prize \\
\hline & & 1: James Tait Black Memorial Prize; Hawthornden Prize; Somerset Maugham Award; WH Smith \\
\hline & & Prize; Whitbread Prize/Costa Award; Guardian Fiction Prize; Orange Prize \\
\hline & Canada & 1: Governor General's Literary Award; Lorne Pierce Medal; Toronto Book Award; Books in \\
\hline & & Canada First Novel Award \\
\hline & Australia & 1: Vance Palmer Prize; ALS Gold Medal; New South Wales Premier's Literary Award; Miles \\
\hline & & Franklin Award \\
\hline & else & 1: Commonwealth Writer's Prize \\
\hline French & France & 2: Prix Goncourt*; \\
\hline \multirow[t]{8}{*}{ language } & & 1: Prix Fémina*; Prix Renaudot*; Prix Médicis*; Prix Interallié*; Grand Prix du Roman*; \\
\hline & & Grand Prix de Littérature; Grand Prix de littérature Paul Morand; Prix des Deux Magots; Prix Roger \\
\hline & & Nimier; Prix Novembre/Decembre \\
\hline & Canada & 1: Prix Littéraires du Gouverneur Général; Médaille de l’Académie des Lettres du Québec; Grand \\
\hline & & Prix de Montréal \\
\hline & Suisse & 1: Grand Prix Schiller; Prix Schiller; Gottfried-Keller-Preis; Prix Rambert \\
\hline & & Triennal du Roman); Prix Victor Rossel \\
\hline & else & 1: Grand Prix littéraire de l'Afrique noire \\
\hline German & Germany & 2: Georg-Büchner-Preis*; Deutsche Buchpreis \\
\hline \multirow[t]{7}{*}{ language } & & 1: Bremer Literaturpreis*; Heinrich-Heine-Preis*; Kleist-Preis*; Hermann-Hesse-Preis*; Heinrich- \\
\hline & & Mann-Preis; Heinrich-Böll-Preis; Nelly-Sachs-Preis; Friedrich-Hölderlin-Preis; Peter-Huchel-Preis; \\
\hline & & Hans-Fallada-Preis; Deutscher Kritikerpreis (Literatur); Grosser Literaturpreis der Bayerischen \\
\hline & & Akademie der Schönen Künste/Thomas-Mann-Preis; Berliner Literaturpreis \\
\hline & Austria & 1: Ingeborg-Bachmann-Preis*; Grosser Österreichischer Staatspreis für Literatur; Preis der Stadt \\
\hline & & Wien für Literatur; Franz-Nabl-Preis \\
\hline & Suisse & 1: Grosser Schillerpreis; Schillerpreis; Gottfried-Keller-Preis; Conrad-Ferdinand-Meyer-Preis \\
\hline Dutch & Netherlands & 2: PC Hooftprijs*; AKO Literatuurprijs* \\
\hline \multirow[t]{7}{*}{ language } & & 1: Prijs der Nederlandse Letteren; Constantijn Huygensprijs*; Lucy B. en C.W. van der Hoogtprijs; \\
\hline & & Multatuliprijs*; F. Bordewijkprijs*; Reina Prinsen Geerligs-prijs; Anton Wachterprijs; Geertjan \\
\hline & & Lubberhuizen-prijs; Tollensprijs; H. Roland Holstprijs; Libris literatuurprijs* \\
\hline & Belgium & 1: Grote Staatsprijs/Oeuvreprijs van de Vlaamse Gemeenschap; Prijs v/d Vlaamse Gemeenschap \\
\hline & & voor Proza; Gouden Uil \\
\hline & International & 3: Nobel Prize for Literature*; \\
\hline & & 1: Friedenspreis des Deutschen Buchhandels; Jerusalem Prize; Hans Christian Andersen Award; \\
\hline
\end{tabular}




\begin{tabular}{|c|c|c|}
\hline & & $\begin{array}{l}\text { Neustadt Prize; Österreichischer Staatspreis für Europäische Literatur; Premios Príncipe de } \\
\text { Asturias de las Letras; Aristeion Prize; IMPAC Dublin Literary Award } \\
\text { Prix de Meilleur Livre étranger; Prix Médicis étranger; Prix Fémina étranger; Premio Mondello; } \\
\text { Premio Grinzane Cavour (Internacional + Narrativa Straniera); Premio Flaiano; Manès-Sperber- } \\
\text { Preis; Franz-Kafka-Preis }\end{array}$ \\
\hline $\begin{array}{l}\text { Spanish } \\
\text { language }\end{array}$ & Spain & $\begin{array}{l}\text { 1: Premio Cervantes; Premio Planeta de Novela; Premios Nadal; Premio de la Crítica de Narrativa } \\
\text { Castellana; Premio Biblioteca Breve; Premio Alfaguarra de Novela; Premio Nacional de las Letras } \\
\text { Españolas; Premio Nacional de Narrativa }\end{array}$ \\
\hline & various & $\begin{array}{l}\text { 1: Premios Rómulo Gallegos; Premio Nacional de Literatura de Chile; Premio Casa de las } \\
\text { Américas; Premio Nacional de Ciencias y Artes (Lingüística y Literatura)(Mexico); }\end{array}$ \\
\hline $\begin{array}{l}\text { Italian } \\
\text { language }\end{array}$ & Italy & $\begin{array}{l}\text { 1: Premio Viareggio; Premio Strega; Premio Bagutta; Premio Campiello; Premio Mondello; Premio } \\
\text { Flaiano; Premio Grinzane Cavour }\end{array}$ \\
\hline $\begin{array}{l}\text { Portugese } \\
\text { language }\end{array}$ & Portugal, Brazil & $\begin{array}{l}\text { 1: Prêmio Camões; Prêmio Machado de Assis; Prêmio Juca Pato; Grande Prêmio de Romance e } \\
\text { Novela APE/IPLB }\end{array}$ \\
\hline Scandinavian & $\begin{array}{l}\text { Sweden, Norway, } \\
\text { Denmark, } \\
\text { Finland, Iceland }\end{array}$ & $\begin{array}{l}\text { 1: Nordic Prize (also nominations); Norwegian Critics Prize for Literature; Samfundet de Nio stora } \\
\text { pris (Sweden); Danish Academy best author prize; Finlandia Prize (best novel); Icelandic Literary } \\
\text { Prize }\end{array}$ \\
\hline Other & various & $\begin{array}{l}\text { 1: Jaroslav-Seifert-Preis (Tschech) Russian Booker Prize; Bialik Prize (Isr); Hertzog Prize (ZAF); } \\
\text { Olive Schreiner Prize (ZAF); Naoki Prize (Jap); Akutagawa Prize (Jap); Yomiuri Prize (Jap); } \\
\text { Tanizaki Prize (Jap) }\end{array}$ \\
\hline
\end{tabular}

'3' refers to weight of three; '2' to weight of two and '1' to a weight of one.

* Prizes are also used to establish prestige of publishers. 
Table A2: Sources of Encyclopedia data

\begin{tabular}{|c|c|c|c|c|}
\hline Language & 1955 & 1975 & 1995 & 2005 \\
\hline French & $\begin{array}{l}\text { Dictionnaire } \\
\text { biographique des } \\
\text { auteurs (1957) } \\
\end{array}$ & $\begin{array}{l}\text { Dictionnaire des } \\
\text { litteratures (1968) }\end{array}$ & $\begin{array}{l}\text { Le nouveau } \\
\text { dictionnaire des } \\
\text { auteurs (1994) } \\
\end{array}$ & $\begin{array}{l}\text { Encyclopedie de la } \\
\text { litterature (2003) }\end{array}$ \\
\hline German & $\begin{array}{l}\text { Lexikon der } \\
\text { Weltliteratur (1950) }\end{array}$ & $\begin{array}{l}\text { Wilpert Lexikon der } \\
\text { Weltliteratur (1975) }\end{array}$ & $\begin{array}{l}\text { Literatur Brockhaus } \\
\text { (1988) }\end{array}$ & $\begin{array}{l}\text { Der Brockhaus } \\
\text { Literatur (2004) }\end{array}$ \\
\hline Dutch & $\begin{array}{l}\text { Encyclopedie van de } \\
\text { Wereldliteratuur } \\
\text { (1954) }\end{array}$ & $\begin{array}{l}\text { Auteurs van de } 20 \mathrm{e} \\
\text { eeuw }(1966) * *\end{array}$ & $\begin{array}{l}\text { Oosthoek lexicon } \\
\text { van de Nederlandse } \\
\text { en Vlaamse } \\
\text { literatuur }(1996)^{*}\end{array}$ & $\begin{array}{l}2000 \text { auteurs uit de } \\
20^{\mathrm{e}} \text { eeuw (2002) } * *\end{array}$ \\
\hline English & $\begin{array}{l}\text { Cassell's } \\
\text { encyclopedia of } \\
\text { world literature } \\
\text { (1953) }\end{array}$ & $\begin{array}{l}\text { Cassell's } \\
\text { encyclopedia of } \\
\text { world literature } \\
\text { (1973) }\end{array}$ & $\begin{array}{l}\text { Merriam Webster } \\
\text { encyclopedia of } \\
\text { modern literature } \\
(1995)\end{array}$ & $\begin{array}{l}\text { Encyclopedia of } \\
\text { world literature in } \\
\text { the } 20^{\text {th }} \text { century } \\
(1999) \\
\text { Benet's reader } \\
\text { encyclopedia (2008) }\end{array}$ \\
\hline
\end{tabular}

\footnotetext{
* only Dutch language authors (not used for calculating international score)

** Two $19^{\text {th }}$ century authors receive domestic scores from encyclopedias of preceding period.
} 
Table A3: Sources of Bestseller list data

\begin{tabular}{|c|c|c|c|c|}
\hline Country & 1955 & 1975 & 1995 & 2005 \\
\hline France & $\begin{array}{l}\text { List of well sold } \\
\text { books in France } \\
\text { published between } \\
\text { 1945-1955, ordered } \\
\text { by author } \\
\text { (Quid, 1977) }\end{array}$ & $\begin{array}{l}\text { Monthly (1965-1966) } \\
\text { and weekly top 10 } \\
\text { lists (1966-1974) in } \\
L^{\prime} \text { Express }\end{array}$ & $\begin{array}{l}\text { Weekly fiction top } \\
10(1985-1990) \\
\text { and top } 15 \text { lists } \\
(1990-1994) \text { in } \\
\text { L'Express }\end{array}$ & $\begin{array}{l}\text { Weekly fiction top } \\
15 \text { (1995-2002) and } \\
\text { top } 20 \text { lists (2002- } \\
\text { 2004) in } L^{\prime} \text { 'Express }\end{array}$ \\
\hline Germany & $\begin{array}{l}\text { Various lists of well } \\
\text { sold books in } \\
\text { Germany published } \\
\text { between 1945-1955 } \\
\text { (Der Spiegel, 30/7/ } \\
\text { 1952; 14/1/1953; } \\
\text { Faulstich, 1983; } \\
\text { Zierman, 2000) }\end{array}$ & $\begin{array}{l}\text { Weekly fiction top } 10 \\
\text { lists (1965-1974) in } \\
\text { Der Spiegel }\end{array}$ & $\begin{array}{l}\text { Weekly fiction top } \\
10(1985-1987) \\
\text { and top } 15 \text { list } \\
(1987-1994) \text { in Der } \\
\text { Spiegel }\end{array}$ & $\begin{array}{l}\text { Weekly fiction top } \\
15 \text { (1995-2001) and } \\
\text { top } 20 \text { lists (2001- } \\
\text { 2004) in Der Spiegel }\end{array}$ \\
\hline Netherlands & $\begin{array}{l}\text { Janssen (1959): list of } \\
\text { most read } \\
\text { authors/books in } \\
1952 \text { survey among } \\
\text { book readers in the } \\
\text { Netherlands }\end{array}$ & $\begin{array}{l}\text { Weekly top } 10 \text { lists } \\
\text { (1968-1973) in } \\
\text { Nieuwsblad voor de } \\
\text { Boekhandel; and } \\
\text { weekly top } 10 \text { lists } \\
\text { (1974) in Haagse } \\
\text { Post }\end{array}$ & $\begin{array}{l}\text { Weekly fiction top } \\
10 \text { lists (1985- } \\
\text { 1994) in Vrij } \\
\text { Nederland (Libris } \\
\text { book stores) }\end{array}$ & $\begin{array}{l}\text { Weekly fiction top } \\
10 \text { lists (1995-2001) } \\
\text { in Vrij Nederland; } \\
\text { weekly fiction top } \\
10 / 15 \text { lists at } \\
\text { CPNB.nl (2002- } \\
2004)\end{array}$ \\
\hline United States & $\begin{array}{l}\text { Authors listed in New } \\
\text { York Times fiction } \\
\text { top } 10 \text { according to } \\
\text { Justice }(1990)\end{array}$ & $\begin{array}{l}\text { Weekly fiction top } 10 \\
\text { lists (1965-1974) in } \\
\text { New York Times }\end{array}$ & $\begin{array}{l}\text { Weekly hardcover } \\
\text { fiction top } 15 \text { lists } \\
(1985-1994) \text { in } \\
\text { New York Times }\end{array}$ & $\begin{array}{l}\text { Weekly hardcover } \\
\text { fiction top } 15 \text { lists } \\
\text { (1995-2004) in New } \\
\text { York Times }\end{array}$ \\
\hline
\end{tabular}

Sources: Quid 1977

Faulstich, W. (1983). Bestandsaufnahme Bestsellerforschung. Wiesbaden: Otto Harrassowitz.

Zierman, K. (2000). Der deutsche Buch- und Taschenbuchmarkt 1945-1995. Berlin: Wissenschaftsverlag Volker Spiess.

Janssen, M.J. (1959). Boeken kiezen voor anderen. Den Haag: Uitgeversfonds van de Centrale Vereniging voor O.L.B. en de Nederlandse Vereniging van Bibliothecarissen.

Justice, K.L. (1990). Bestseller Index. Jefferson, NC: McFarland. 
Table A4: Merging of institutional data and newspaper data

\begin{tabular}{llll}
\hline Origin & Authors from countries of & Authors from countries & Authors from countries \\
Institutions & sample newspapers & with same language as & with other language than \\
& (F, G, N, U) & sample newspapers & sample newspapers \\
\hline Domestic & ENC (own language) & ENC (same language) & - \\
& LP (own language) & LP (same language) & LP (own language) \\
& BE (own country) & - & - \\
\hline International & ENC (mean other & ENC (mean other & ENC (mean all \\
& languages) & languages) & languages) \\
& LP (int. prizes + other & LP (int. prizes + other & LP (int. prizes + other \\
& languages) & languages) & languages) \\
& BE (mean other cou.) & BE (mean all countries) & BE (mean all countries) \\
\hline No & PUB (publisher in & PUB (publisher in & PUB (publisher in \\
distinction & country newspaper)* & country newspaper)* & country newspaper)*
\end{tabular}

ENC=Encyclopedia; LP=Literary prize; BE=Bestseller list; PUB=Publisher.

* If no publisher was found or only a foreign publisher (in the case of books which were not translated), authors received the minimal score.

Appendix B: Results Cluster analysis

\begin{tabular}{|l|l|l|l|l|l|l|l|l|l|l|l|}
\hline & \multicolumn{2}{|l|}{$\begin{array}{l}\text { Dom } \\
\text { lp }\end{array}$} & Int lp & $\begin{array}{l}\text { Dom } \\
\text { be }\end{array}$ & Int be & $\begin{array}{l}\text { Aut } \\
\text { dead }\end{array}$ & $\begin{array}{l}\text { Dom } \\
\text { enc }\end{array}$ & $\begin{array}{l}\text { Int } \\
\text { enc }\end{array}$ & $\begin{array}{l}\text { Pub } \\
\text { aut }\end{array}$ & $\begin{array}{l}\text { Pub } \\
\text { lp }\end{array}$ \\
\hline 1955 & $1-57.1 \%(218)$ & $*$ & & $*$ & $*$ & $*$ & $*$ & $*$ & & $*$ \\
\hline & $2-24.3 \%(93)$ & $*$ & $*$ & $*$ & $*$ & $*$ & $*$ & & $*$ & $*$ \\
\hline & $3-18.6 \%(71)$ & & & & $*$ & $*$ & $*$ & $*$ & & $*$ \\
\hline
\end{tabular}

* significant contribution according to Chi-Square test

$\mathrm{BIC}=$ Schwarz's Bayesian Criterion; RDM=Ratio of Distance Measures 


\footnotetext{
${ }^{\mathrm{i}}$ The sampling method of the constructed week is a specific form of stratified sampling: every week day is represented equally, but not from the same weeks to avoid bias towards particularities of one news week (Riffe, Aust, and Lacy 1993). So there might be a Monday edition from week 1, a Tuesday edition from week 5, etc. In our case, we constructed four weeks, one for each quarter of the year to account for seasonal biases.

ii The year 2005 actually concerned the latter half of 2004 and the first half of 2005. For the Los Angeles Times only three constructed weeks were sampled. Magazines were left out the analyses. The particular years were chosen for a couple of reasons: 1) since the original project aimed to map postwar transitions in classification systems the starting point was the 1950s, 2) decade spreads were the result of balancing a) the aim to cover a substantial historical period, b) the level of detail in the analysis of individual newspapers, and c) time/financial restrictions, 3) the data were collected in 2005/2006.

iii For 1955, we took the period 1940-1955, since not many awards already existed before.

${ }^{\text {iv }}$ Bestseller lists were recoded as $1=0 ; 2=1 ; 3=2-3 ; 4=4-10 ; 5=10+$. Literary prizes were recoded as $1=0 ; 2=1$; $3=2-3 ; 4=3+$.

${ }^{v}$ Note that the number of characteristics is somewhat limited because of the difficulty of finding background information on $1000+$ authors from 3 countries for a period dating back to the 1950s.
} 